Marek MUSIOŁ

Uniwersytet Wrocławski, Wydział Nauk Społecznych, Polska

\title{
Znaczenie sekurytyzacji i sektorów bezpieczeństwa w ramach krytycznych studiów nad bezpieczeństwem
}

\author{
The Importance of Securitization and Security Sectors \\ as a Part of the Critical Security Studies
}

\section{- Abstrakt •}

Od lat 80. XX wieku trwa debata związana $\mathrm{z}$ ewolucją pojęcia bezpieczeństwo i jego wymiarów. Szkoła kopenhaska wraz z koncepcjami sekurytyzacji i sektorów bezpieczeństwa ściśle wpisuje się w ten dyskurs bezpieczeństwa oraz krytykę tradycyjnych paradygmatów, niebędących w stanie przewidzieć upadku ZSRR i końca zimnej wojny. Przedmiotem artykułu jest zatem zaprezentowanie znaczenia głównych założeń krytycznych studiów nad bezpieczeństwem na przykładzie szkoły kopenhaskiej oraz intersubiektywnego podejścia do bezpieczeństwa w jego wielowymiarowym ujęciu.

Słowa kluczowe: bezpieczeństwo, security studies, krytyczne studia nad bezpieczeństwem, sekurytyzacja, szkoła kopenhaska, sektory bezpieczeństwa

\section{- Abstract •}

Since the 1980s, there has been a debate about the evolution of the notion of security and its dimensions. The Copenhagen School, and its key concepts such as securitization, and security sectors, closely keep up with this security discourse and criticize traditional paradigms that could not predict the collapse of the USSR and the end of the Cold War. Therefore, the subject of this paper is to present the importance of main assumptions of critical security studies using the example of the Copenhagen School and the intersubjective approach to security in its multidimensional aspect.

Keywords: security, security studies, critical security studies, securitization, Copenhagen School, security sectors

\section{Wstęp}

W niniejszym artykule wykorzystałem analizę historyczną i deskryptywną celem przybliżenia najważniejszych uwarunkowań rozwoju studiów nad bezpieczeństwem oraz ich krytycznej formy. W kolejnych podrozdziałach zaprezentowałem genezę studiów nad bezpieczeństwem (security studies) oraz najważniejsze 
etapy ich ewolucji. Za punkt referencyjny przyjąłem krytyczne studia nad bezpieczeństwem, w które wpisują się koncepcje szkoły kopenhaskiej. W tym kontekście uznałem, że bardzo użyteczne walory w badaniach nad bezpieczeństwem wykazują zarówno analiza sekurytyzacyjna, jak i analiza sektorów bezpieczeństwa. W związku z tym w końcowej części artykułu postaram się wykazać aplikacyjne i utylitarne znaczenie wspomnianych koncepcji w analizie istniejących zagrożeń dla porządku i bezpieczeństwa międzynarodowego jako kategorii badawczych.

Wśród źródeł mających pomocniczy charakter w stosunku do opracowywanego przeze mnie artykułu na uwagę zasługują prace takich autorów, jak: Barry Buzan, Ole Weaver, Jaap de Wilde, Juha Vuori, Lene Hansen, David Baldwin, Brendan Taylor czy Wojciech Kostecki.

Wspomniani autorzy wnieśli istotny wkład na rzecz rozwoju literatury przedmiotu, zgłębienia znaczenia studiów nad bezpieczeństwem i teorii sekurytyzacji oraz poszerzenia wiedzy w tym obszarze.

\section{Prekursorskie inicjatywy - badania nad wojną i pokojem po I wojnie światowej}

Rozważania na temat wojny i pokoju sięgają starożytności. Do wybitnych myślicieli tego okresu zajmujących się tymi kwestiami należeli Sun Tzu (544-496 p.n.e.) czy Tukidydes (460-395 p.n.e.). Sun Tzu był autorem Sztuki wojny, której założenia w kontekście planowania strategicznego nie straciły na aktualności. Jego dzieło jest uznawane za najstarszy w historii podręcznik w zakresie sztuki wojennej. Natomiast Tukidydes w swojej monografii zatytułowanej Wojna peloponeska w sposób precyzyjny oddał przebieg konfliktu. W ten kierunek rozważań filozoficznych wpisywała się także starożytna rzymska maksyma autorstwa Wegecjusza (385-400), która w języku łacińskim brzmi Si vis pacem, para bellum (dosł. „Jeśli chcesz pokoju, gotuj się do wojny").

Średniowiecze wykreowało koncepcje wojny sprawiedliwej i niesprawiedliwej. W tej rzeczywistości obowiązującego uniwersalizmu (religia chrześcijańska, język łaciński, władza duchowa i świecka) podstawą rozróżnienia wojny sprawiedliwej od niesprawiedliwej był fakt jej wypowiedzenia oraz wskazania konkretnego powodu jej wywołania.

Natomiast w czasach nowożytnych i kolejnych stuleciach warto przywołać m.in. Niccolo Machiavellego (1469-1527), Thomasa Hobbesa (1588-1679) czy Carla Clausewitza (1780-1831). Niccolo Machiavelli w swoim dziele pt. Książe nie tylko zapisał się jako twórca traktatu o władzy i polityce („cel uświęca środ- 
ki”), ale także opowiadał się za armią składającą się z obywateli danego kraju, motywowaną pobudkami patriotycznymi, nie zaś nastawioną na zysk. Wreszcie należy wspomnieć o dziele $O$ wojnie autorstwa Carla Clausewitza (1780-1831), którego założenia zapisały się jako podstawy wojen konwencjonalnych w XIX i XX wieku. Do jego najbardziej znanych stwierdzeń należą: „wojna jest jedynie kontynuacją polityki innymi środkami” oraz „pokój to zawieszenie broni pomiędzy dwiema wojnami".

Jednak w zakresie badań nad wojną i pokojem to I wojna światowa w ujęciu Clausewitzowskim odcisnęła największe piętno, a po jej zakończeniu wśród polityków i intelektualistów zaczęło dominować podejście idealistyczno-pacyfistyczne. Takie podejście było następstwem pierwszej wojny totalnej w historii ludzkości. W takich warunkach utopistycznych wizji porządku międzynarodowego okresu międzywojnia Woodrow Wilson zaproponował swoją koncepcję, składającą się z 14 punktów, co dało podstawę dla utworzenia pierwszej uniwersalnej organizacji systemu bezpieczeństwa zbiorowego, tj. Ligi Narodów.

W tym czasie zaczęły także powstawać pierwsze ośrodki naukowo-akademickie oraz wykształtowały się pierwsze nurty badawcze takie jako polemologia w zakresie badań nad wojną czy irenologia zajmująca się analizą pokoju i jego przesłanek (Stadtmüller, 2002). Polemologia wywodzi się z greckiego terminu polemos, co oznacza wojnę. Wybitnym przedstawicielem tego nurtu, którego początki sięgają XX wieku, był Gaston Bouthoul (1896-1980). Był on też twórcą pierwszego instytutu polemologicznego - Institut Francais de Polémologie w Paryżu w 1945 roku. Do innych polemologów należeli Pitirim Sorokin (1889-1968) oraz Quincy Wright (1890-1970).

W XX wieku zaczęły rozwijać się ośrodki zajmujące się badaniami nad pokojem, zwanymi całościowo irenologią (gr. eirene - pokój), które po II wojnie światowej - od lat 50. XX wieku - zaczęto określać mianem peace research. Wówczas powstały takie instytuty I inicjatywy jak Research Exchange on the Prevention of War (1952, USA), Pugwash Movement (1957), Peace Research Institute in Oslo (1959, Norwegia), International Peace Research Association in London (1968, Wielka Brytania), Stockholm International Peace Research Institute (1966, Szwecja; Stadtmüller, 2002). Do przedstawicieli irenologii i szeroko rozumianych badań nad pokojem zaliczyć można Johana Galtunga, Alvę Myrdal, Gunnara Myrdala oraz Bertranda Russella.

Współcześnie w te zagadnienia wpisują się raporty i analizy opracowywane przez Institute for Economics and Peace (IEP) w kontekście pokoju, Bonn International Center for Conversion (BICC) czy Heidelberg Institute for International Conflict Research (m.in. Conflict Barometer) w obszarze szeroko rozumianej woj- 
ny. Poniżej zaprezentowano przykładowe wnioski z raportów Institute for Economics and Peace (IEP) - Global Peace Index 2017 oraz Positive Peace Report 2016.

Mapa 1. Stan pokoju na świecie według Global Peace Index 2017

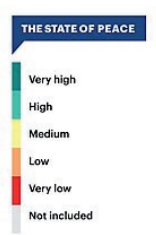

\section{GLOBAL PEACE INDEX}

A SNAPSHOT OF THE GLOBAL STATE OF PEACE

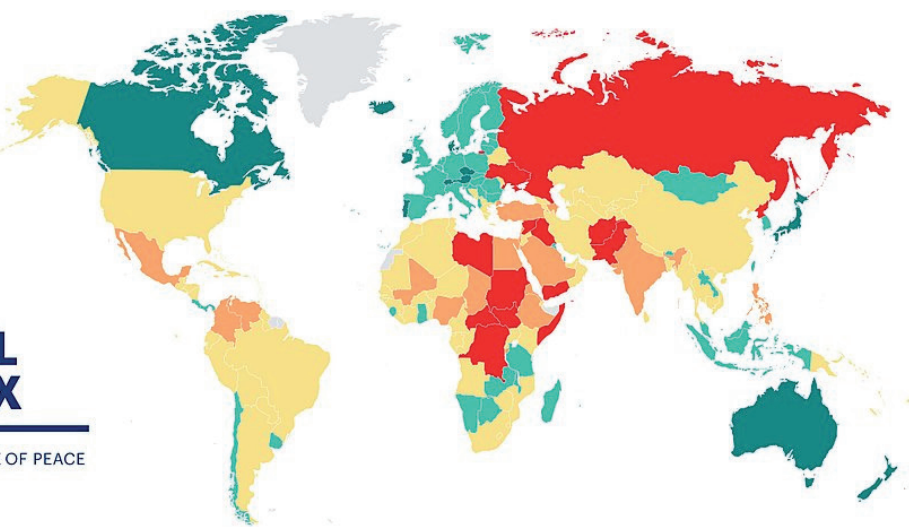

Źródło: Global Peace Index (2017). Pobrano z: http://visionofhumanity.org/app/uploads/2017/06/ GPI17-Report.pdf.

Rysunek 1. Filary pozytywnego pokoju

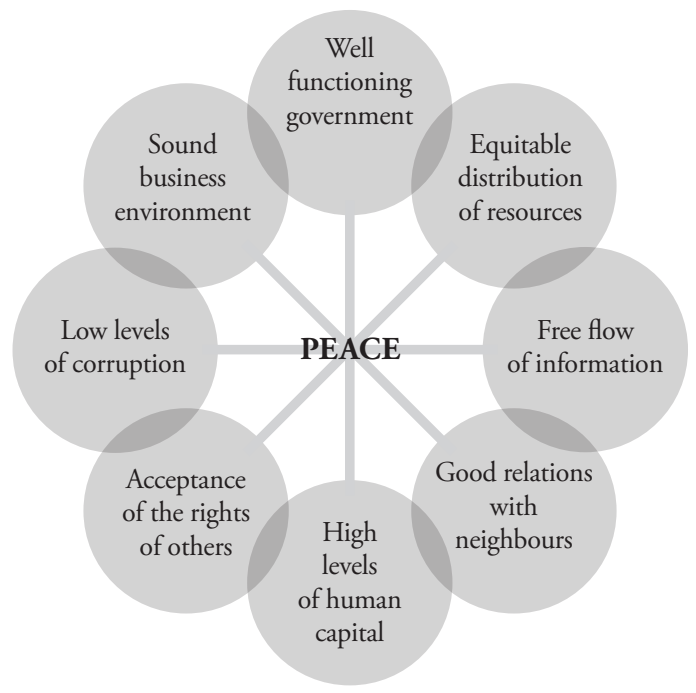

Źródło: Positive Peace Report (2016). Pobrano z: http://visionofhumanity.org/app/uploads/2017/02/ Positive-Peace-Report-2016.pdf. 


\section{Geneza i ewolucja studiów nad bezpieczeństwem}

W XIX wieku bezpieczeństwo, problemy wojny i pokoju stają przedmiotem badań naukowych. Do XIX wieku zajmowano się przede wszystkim zagadnieniami związanymi z wojną, która stanowiła odniesienie dla rozważań filozoficznych. Początki studiów nad bezpieczeństwem (security studies) jako podstawy analitycznej i podejścia akademickiego sięgają pierwszej połowy XX wieku. To wówczas w USA powstały (zresztą istniejące do dzisiaj) ośrodki analityczne i periodyki, mające istotne przełożenie opiniotwórcze na politologów i internacjologów oraz na polityczne ośrodki decyzyjne. Warto tutaj wspomnieć o takich przejawach instytucjonalizacji jak utworzenie Carnegie Endowment for International Peace w Waszyngtonie (1910, USA), World Peace Foundation w Medford (1910, USA) czy czasopisma „Foreign Affairs” w Nowym Jorku (1922, USA).

Jednak zdecydowana większość ekspertów utrzymuje, że kluczową rolę dla rozwoju security studies odegrały lata 40 . XX wieku wraz z uruchomieniem specjalistycznych i naukowych czasopism jak „International Organisation” (1947) czy „World Politics” (1948) oraz powołaniem RAND Corporation w 1948 roku w Santa Monica w USA - jako jednego z pierwszych ośrodków analitycznych typu think tank. Do analityków RAND Corporation należeli między innymi Condoleezza Rice, Donald Rumsfeld czy Francis Fukuyama. Powstanie tego ośrodka oraz artykuł Bernarda Brodiego pt. Strategy as a Science (Brodie, 1949) na łamach „World Politics” przyczyniły się do narodzin w USA narodowych studiów nad bezpieczeństwem (National Security Studies) na poziomie akademickim. W tej pierwszej fazie rozwoju studiów bezpieczeństwa, tj. w latach 40. i 50. XX wieku, badania były zdominowane przez różnorodne aspekty militaryzacji stosunków międzynarodowych, a głównym celm państw było bezpieczeństwo narodowe. Studia nad bezpieczeństwem koncentrowały się wtedy na badaniu przyczyn, efektów i zapobieganiu wojnom. W analizy te wpisywała się także aktywność Center for Research on Conflict Resolution, które zostało powołane przy Ann Arbor University w 1955 roku. Z kolei rozwój badań nad pokojem w USA po II wojnie światowej był możliwy dzięki odprężeniu w relacjach Wschód-Zachód po śmierci Józefa Stalina i objęciu władzy przez Nikitę Chruszczowa.

Kolejny etap ewolucji studiów nad bezpieczeństwem określany jest terminem Golden Age. Okres ten przypada na lata 1955-1965 (Baldwin, 1995). Przedmiot badań zdeterminowany był znaczeniem arsenałów nuklearnych, działaniami na rzecz kontroli broni, ograniczonymi wojnami oraz strategią odstraszania (deterrence; Baldwin, 1995). Teoria odstraszania była głównym rezultatem wysiłków analityków i polityków. Doktryna ta była pod silnym wpływem realistycznej teorii sto- 
sunków międzynarodowych oraz opierała się na założeniu, że wszystkie rządy zachowują się racjonalnie. Zatem podstawowym przekonaniem była konstatacja, że możliwości nuklearne kraju mogą być zorganizowane w taki sposób, aby odwieść inne podmioty od angażowania się w wymianę potencjału jądrowego i odwrotnie (Taylor, 2012).

Pod koniec lat 60. i w latach 70. XX wieku rozpoczyna się sukcesywna internacjonalizacja studiów nad bezpieczeństwem oraz powrót do badań nad pokojem (peace research), które intensywnie rozwijały się przed wybuchem II wojny światowej (Baldwin, 1995). Ten etap ewolucji pokrywa się z fazą odprężenia w stosunkach międzynarodowych, tzw. detente. Ten proces pokojowej koegzystencji był możliwy na skutek osłabienia pozycji USA po wojnie w Wietnamie oraz rozpoczęcia procesu KBWE i podpisania Aktu końcowego Konferencji Bezpieczeństwa i Współpracy w Europie. W tym czasie zostały także opublikowane artykuły istotne dla transformacji studiów nad bezpieczeństwem, a mianowicie Power and Interdependence (Keohane, Nye, 1977) oraz Theory of International Politics (Waltz, 1979). Robert O. Keohane i Joseph S. Nye twierdzili, że bezpieczeństwo narodowe jest wrażliwe i podatne na rozwój bezpieczeństwa innych państw (Keohane, Nye, 1977). Z kolei K. Waltz zakładał, że państwa w środowisku międzynarodowym zachowują się w podobny sposób, co oznacza, że w anarchicznym międzynarodowym środowisku politycznym ich domyślne położenie determinowane jest dążeniem do osiągnięcia równowagi przeciwko najsilniejszym potęgom w systemie międzynarodowym i alokacją dodatkowych środków na rzecz bezpieczeństwa narodowego (Waltz, 1979).

$\mathrm{Na}$ tym etapie rozwoju security studies $\mathrm{w} 1970$ roku pojawia się także nowy periodyk - „Foreign Policy”, którego inicjatorem jest Samuel Huntington. „Foreign Policy” od 2014 roku publikuje także Fragile States Index (wcześniej pod nazwą Failed States Index).

Na lata 70. i 80. XX wieku przypada rozkwit międzynarodowych studiów nad bezpieczeństwem (International Security Studies; Baldwin, 1995; Taylor, 2012). Przedmiotem ich analiz stają się wzrastające napięcia w stosunkach międzynarodowych w tym okresie oraz akcentowanie wyraźnej współzależności pomiędzy państwami i ich bezpieczeństwem w systemie międzynarodowym. Przełom lat 80. i 90. XX wieku to także okres, w którym studia nad bezpieczeństwem ulegają stopniowo procesom globalizacji, następuje stopniowa redefinicja bezpieczeństwa i zagrożeń. Kończy się zimna wojna. Debaty zdominowane są sporami i krytyką nierzetelnej identyfikacji potencjalnych, politycznych, gospodarczych i społecznych wyzwań w ZSRR i wśród państw Układu Warszawskiego. Główny zarzut sprowadzał się do nadmiernej koncentracji analityków i decydentów na aspektach 
militarnych i arsenałach wojskowych, i jednoczesnym pomijaniu rzeczywistych przyczyn zmian w systemie i środowisku międzynarodowym.

W latach 90. XX wieku w USA powstał też ośrodek analityczno-prognostyczny STRATFOR, który opracowuje coroczne analizy prognostyczne dla wielu regionów świata. Okres ten naznaczony jest wykwitem nowych koncepcji determinujących nowy porządek międzynarodowy po zakończeniu zimnej wojny, takich jak New World Order (George Bush, Michaił Gorbaczow) czy „koniec historii” (Francis Fukuyama).

Tabela 1. Narodowe Studia nad Bezpieczeństwem a Międzynarodowe Studia nad Bezpieczeństwem - główne cechy i różnice

\begin{tabular}{|l|l|}
\hline $\begin{array}{l}\text { Narodowe Studia } \\
\text { nad Bezpieczeństwem }\end{array}$ & $\begin{array}{l}\text { Międzynarodowe Studia } \\
\text { nad Bezpieczeństwem }\end{array}$ \\
\hline Lata 40. i 50. XX wieku & Lata 70. i 80. XX wieku \\
\hline Dominacja realizmu & $\begin{array}{l}\text { Pojawienie się nowych wymiarów } \\
\text { bezpieczeństwa }\end{array}$ \\
\hline Państwa jako jedyni racjonalni aktorzy & Aktorzy państwowi oraz niepaństwowi \\
\hline Dylemat bezpieczeństwa i jego rola & Koniec zimnej wojny i New World Order \\
\hline Era nuklearna i odstraszanie & $\begin{array}{l}\text { Degradacja środowiska } \\
\text { międzynarodowego }\end{array}$ \\
\hline Analiza zdolności nuklearnych państw & $\begin{array}{l}\text { Pojawienie się wyzwań transnarodowych } \\
\text { (WTC w 2001) }\end{array}$ \\
\hline
\end{tabular}

Źródło: opracowanie własne.

\section{Wielowymiarowy charakter bezpieczeństwa i redefinicja zagrożeń jako podstawa rozwoju krytycznych studiów nad bezpieczeństwem}

Stopniowe poszerzanie pojęcia bezpieczeństwa i modyfikacja katalogu zagrożeń stanowią przejaw krytycznych studiów nad bezpieczeństwem (Critical Security Studies), które zapoczątkowane zostały na przełomie lat 80. i 90. XX wieku. Do głównych tematów debat tego nowego nurtu zaliczano między innymi bezpieczeństwo i jego redefinicję, pozycję i status państw w stosunkach międzynarodowych, nowe obiekty odniesienia dla bezpieczeństwa, nowych aktorów w środowisku międzynarodowym czy nowe ujęcia zagrożeń. Główni przedstawiciele tego nurtu w różnoraki sposób definiowali bezpieczeństwo. Zdaniem B. Buzana, O. Wævera i J. de Wilde’a, „bezpieczeństwo jest samoodnoszącą się do siebie prak- 
tyką, ponieważ w ramach tej praktyki dana kwestia staje się problemem bezpieczeństwa - niekoniecznie dlatego, że istnieje prawdziwe egzystencjalne zagrożenie, ale ponieważ dany problem jest przedstawiany jako zagrożenie" (Buzan, Wæver, de Wilde, 1998). Ponadto „bezpieczeństwo ma charakter relacyjny, a zatem zgodnie z założeniami B. Buzana jest to zawsze stosunek między zagrożeniem a możliwościami przeciwstawienia się mu” (Buzan, 1991). Wreszcie Ken Booth przyjmował, że bezpieczeństwo należy rozumieć jako przetrwanie-plus (survival plus), gdzie plus oznacza wolność od jakichkolwiek zagrożeń dla życia ludzkiego (Booth, 2007).

W okresie zimnej wojny koncepcja bezpieczeństwa odnosiła się do ochrony państw jako obiektów odniesienia i wyzwań, które były pojmowane przez pryzmat bezpieczeństwa narodowego. Bezpieczeństwo związane było ściśle z integralnością terytorialną i ochroną suwerenności. Koniec zimnej wojny stanowił jedną z przesłanek na rzecz otwartej redefinicji bezpieczeństwa (wyjścia w kierunku nowych wymiarów, znacznie wykraczających poza militarne uwarunkowania). Proces transformacji znaczenia bezpieczeństwa w stosunkach międzynarodowych jest zatem także wynikiem ewolucji pojmowania bezpieczeństwa przez państwa narodowe. Do głównych przyczyn tego procesu należą:

- rewolucja naukowa i technologiczna,

- rozwój prawa międzynarodowego,

- wzrost znaczenia podmiotów niepaństwowych,

- współzależność międzynarodowa.

Zmiany w środowisku międzynarodowym i jego degradacja miały też istotny wpływ na nowe pojmowanie bezpieczeństwa w stosunkach międzynarodowych.

W ten kontekst wpisuje się również proces wyodrębnienia zagrożeń tradycyjnych i nietradycyjnych, gdzie kluczowym czynnikiem właściwej selekcji i doboru typologii zagrożeń nie jest ich relatywnie współczesny charakter, lecz skala występowania. Do zagrożeń tradycyjnych (lub starych) zaliczyć można konflikty międzypaństwowe, naruszenie suwerenności państw, handel bronią czy rozprzestrzenianie broni masowego rażenia. Natomiast katalog zagrożeń nietradycyjnych (lub nowych) sprowadza się między innymi do terroryzmu międzynarodowego i cyberterroryzmu, kwestii demograficznych, udziału dzieci w konfliktach zbrojnych, transnarodowej przestępczości zorganizowanej, zjawiska państw upadłych, HIV/AIDS, epidemii, globalnych zmian klimatycznych i separatyzmu etnicznego (Kurdowie, Katalończycy).

W trakcie zarysowanej powyżej ewolucji i wspomnianych debat wykształciły się główne szkoły w zakresie krytycznych studiów nad bezpieczeństwem, takie jak: Szkoła Kopenhaska (B. Buzan, O. Wæver, L. Hansen, J. de Wilde), Szko- 
ła Walijska (K. Booth), Szkoła Paryska (J. Huysmans) czy niektóre podejścia postmodernistyczne oraz feministyczne, podejmujące problemy bezpieczeństwa w zawężonych i zaadaptowanych do swoich potrzeb interpretacjach.

Rysunek 2. Relacje pomiędzy niebezpieczeństwem, bezpieczeństwem i jego brakiem

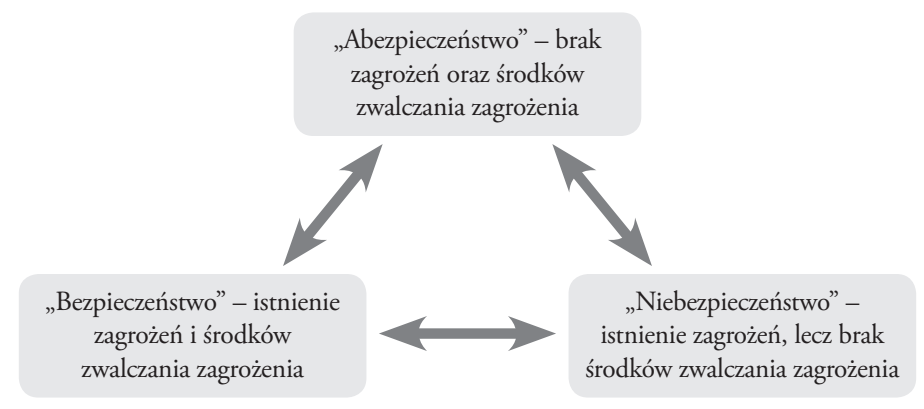

Źródło: Vuori (2011). Zob. także: Musioł (2015).

\section{Sektory bezpieczeństwa i sekurytyzacja jako użyteczne narzędzia analityczne w krytycznych studiach nad bezpieczeństwem}

Koncepcje sektorów bezpieczeństwa i sekurytyzacji zostały wypracowane w ramach Kopenhaskiej Szkoły Studiów nad Bezpieczeństwem (the Copenhagen Peace Research Institute - COPRI). Ten instytut badawczy został powołany w 1985 roku. W styczniu 2003 roku został włączony do Duńskiego Instytutu Studiów Międzynarodowych (the Danish Institute for International Studies). Z tym ośrodkiem związani byli lub nadal są O. Wæver, B. Buzan. J. de Wilde i L. Hansen. Nazwę Szkoła Kopenhaska po raz pierwszy zastosował B. McSweeney w 1994 roku.

Pierwszą zarysowaną powyżej koncepcją metodologiczną są sektory bezpieczeństwa. „Sektory bezpieczeństwa to obszary/pola aktywności lub areny, które pociągają za sobą szczególne formy interakcji bezpieczeństwa i szczególne definicje obiektów odniesienia" (Williams, 2008). Przedstawiciele Szkoły Kopenhaskiej w toku badań wyodrębnili następujące sektory bezpieczeństwa: militarny, państwowy/polityczny, społeczny, ekonomiczny, ochrony środowiska naturalnego (Buzan, Wæver, de Wilde, 1998). Istotę poszczególnych sektorów oddaje poniższa tabela, w której wskazane zostały, za Wojciechem Kosteckim, najważniejsze aspekty zagrożeń dla kluczowych wartości w obrębie wymienionych sektorów. 
Tabela 2. Sektory bezpieczeństwa

\begin{tabular}{|l|l|}
\hline Polityczny/państwowy & Suwerenność \\
\hline Militarny & Przetrwanie \\
\hline Społeczny & Tożsamość \\
\hline Ekonomiczny & Dobrobyt \\
\hline Ochrony środowiska naturalnego & Zrównoważony rozwój \\
\hline
\end{tabular}

Źródło: opracowanie własne na podstawie: Kostecki (1996).

Jak twierdzą B. Buzan, O. Wæver i J. de Wilde, w ramach sektorów bezpieczeństwa mogą przebiegać procesy sekurytyzacji. Jednak co ważne, sama sekurytyzacja może występować w wielu sektorach bezpieczeństwa, nie zawsze tylko w jednym. Wskazane klasyczne wymiary bezpieczeństwa stanowią bardzo przydatną wskazówkę przy analizie wielowymiarowej natury bezpieczeństwa.

Natomiast idea drugiej wymienionej koncepcji - teorii sekurytyzacji sprowadza się do ontologii postrzegania świata jako obszaru uporządkowanego przez mówców, akty mowy i odbiorców. „Teoria sekurytyzacji powstała pod koniec lat 80. XX w. Po raz pierwszy została zaprezentowana przez O. Wæevera w ramach COPRI w 1995 r. Istotą teorii jest idea, że coś staje się problemem dla bezpieczeństwa nie tylko dlatego, że stanowi obiektywne zagrożenie dla państwa (jak np. $\mathrm{w}$ neorealizmie), ale staje się kwestią bezpieczeństwa, kiedy aktor sekurytyzujący (często państwo) argumentuje, że coś stanowi egzystencjalne zagrożenie dla jakiegoś obiektu i musi być rozpatrywane natychmiast, gdy tylko celem jest jego przetrwanie" (Musioł, 2015). Zatem zgodnie z tym założeniem, proces sekurytyzacji zakłada przeniesienie danego problemu ze sfery polityki do sfery bezpieczeństwa.

W teorii sekurytyzacji bezpieczeństwo jest utożsamiane z przetrwaniem i formułowanym aktem mowy w formie werbalnej lub niewerbalnej. Do kluczowych elementów struktury tego procesu należą aktorzy sekurytyzujący, obiekty odniesienia i odbiorcy. Sukces lub porażka procesu sekurytyzacji wynika z właściwej identyfikacji zagrożeń egzystencjalnych, nadzwyczajnej sytuacji oraz skutków złamania przyjętych zasad i wpływu tych działań na relacje miedzy poszczególnymi jednostkami. Do warunków ułatwiających transformację postrzegania problemu przez grupy docelowe należą między innymi pozycja aktora sekurytyzującego oraz jego wpływ na potencjalnych odbiorców. Zagrożenie w tym przypadku nie musi być realne, ważne, żeby było tak postrzegane.

„Najważniejszym aspektem tej metodologii jest pytanie analityczne: w jaki sposób dana kwestia została przekształcona w problem bezpieczeństwa lub ściślej czy stanowi element polityki bezpieczeństwa” (Bueger, 2010). 
Do drugiej generacji badaczy sekurytyzacji w ramach krytycznych studiów nad bezpieczeństwem należą Juha Vuori, Thierry Balzacq, Lene Hansen i Holger Stritzel.

Rysunek 3. Schemat procesu sekurytyzacji

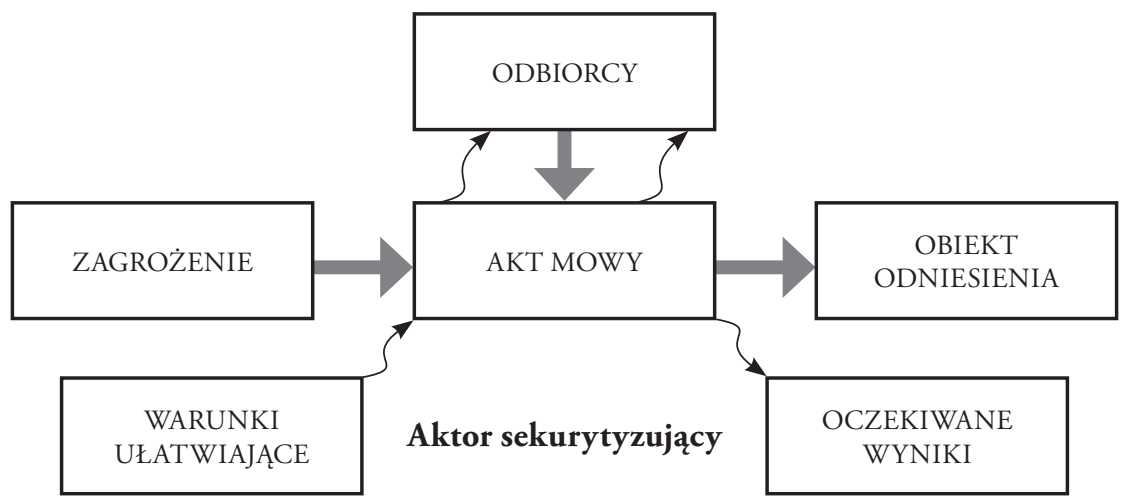

Źródło: opracowanie własne.

Tabela 3. Sekurytyzacja w praktyce - przykładowa struktura

\begin{tabular}{|l|l|}
\hline $\begin{array}{l}\text { Kto jest aktorem } \\
\text { sekurytyzującym? }\end{array}$ & $\begin{array}{l}\text { państwo, społeczeństwo obywatelskie, } \\
\text { międzynarodowe i lokalne organizacje pozarządowe, } \\
\text { agencje ONZ, osoby (działacze ekologiczni), rządy } \\
\text { i ich wojskowe elity, liderzy polityczni, lobby }\end{array}$ \\
\hline Kto jest odbiorcą? & $\begin{array}{l}\text { opinia publiczna, politycy, elity wojskowe, } \\
\text { społeczeństwo, aktorzy rządowi i pozarządowi }\end{array}$ \\
\hline Co jest obiektem odniesienia? & $\begin{array}{l}\text { stabilność gospodarcza i polityczna, tożsamość, } \\
\text { suwerenność, integralność terytorialna }\end{array}$ \\
\hline Co jest aktem mowy? & $\begin{array}{l}\text { oświadczenia, deklaracje, dokumenty, przekazy } \\
\text { medialne, materiały zarówno w formie werbalnej, } \\
\text { jak i niewerbalnej }\end{array}$ \\
\hline $\begin{array}{l}\text { Co jest ruchem } \\
\text { sekurytyzacyjnym? }\end{array}$ & aktor jedynie deklaruje egzystencjalne zagrożenie \\
\hline $\begin{array}{l}\text { Co jest pełnym aktem } \\
\text { sekurytyzacji? }\end{array}$ & $\begin{array}{l}\text { wyznaczeni odbiorcy akceptują dany akt mowy, } \\
\text { przyjmując twierdzenie wpływowych elit } \\
\text { politycznych, że egzystencjalne zagrożenie istnieje, } \\
\text { i następnie zatwierdzają reakcję z użyciem środków } \\
\text { nadzwyczajnych }\end{array}$ \\
\hline
\end{tabular}

Źródło: opracowanie własne na podstawie: Musioł (2015). 


\section{Podsumowanie}

Niniejszy artykuł wpisuje się w powstające już w Polsce analizy na rzecz studiów nad bezpieczeństwem i krytycznych studiów nad bezpieczeństwem (m.in. prace Jacka Czaputowicza, Wojciecha Kosteckiego, Łukasza Fijałkowskiego). Jest przede wszystkim próbą zestawienia najważniejszych założeń z tego obszaru w wymiarze teoretycznym i praktycznym.

Mam nadzieję, że przeanalizowany powyżej materiał oraz ukazane przykładowe struktury i kategorie analityczne przybliżyły praktyczne i utylitarne walory ram metodologicznych i koncepcyjnych Szkoły Kopenhaskiej w badaniach nad problemami bezpieczeństwa i nad jego współczesnym środowiskiem. Niewątpliwą zaletą tych narzędzi jest ich elastyczność i relatywnie wysoka adaptowalność. Wynika to przede wszystkim z faktu, że twórcy tych koncepcji i zarazem przedstawiciele szkoły kopenhaskiej przywiązywali istotną wagę do eklektycznych rozwiązań w nauce, w postaci łączenia elementów różnych paradygmatów takich jak realizm/materializm i konstruktywizm.

Pomimo licznych głosów krytycznych dotyczących wymieszania podstaw teoretyczno-intelektualnych (J.L. Austin, J. Derrida, C. Schmitt, K. Waltz) czy europocentrycznej orientacji, do tej pory nie powstały inne ramy analityczne, które pozwalają badać bezpieczeństwo w jego wielowymiarowym ujęciu, bez względu na aktorów (nie tylko państwa), jak i na ograniczenia paradygmatyczno-teoretyczne. Metodologia ta nie jest też dogmatyczna w odniesieniu do sektorów bezpieczeństwa, zatem koncentruje się nie tylko na sektorze wojskowym.

Konkludując, omówione powyżej kwestie wpisują się we współczesną debatę i dyskurs bezpieczeństwa. Przedstawiona w artykule metodologia jest próbą systematyzacji złożonych zmiennych w zakresie problematyki bezpieczeństwa w aktualnym anarchicznym środowisku międzynarodowym. Pozwala na przeprowadzenie analizy istniejących zagrożeń na różnych płaszczyznach stosunków międzynarodowych, w tym lokalnej, regionalnej i globalnej. Istotnym aspektem szkoły kopenhaskiej jest także uwzględnienie kontekstu kulturowo-społecznego w badaniach nad bezpieczeństwem.

\section{Bibliografia:}

Baldwin, D.A. (1995). Security Studies and the End of the Cold War. World Politics, 48. Booth, K. (2007). Theory of World Security. New York: Cambridge University Press. Brodie, B. (1949). Strategy as a Science. World Politics, Volume 1, Issue 4. 
Bueger, Ch. (2010). Security as Performation: Securitization, Piracy and the United Nations Security Council. Bi-annual conference of the Standing Group for International Relations of the ECPR, Stockholm, European University Institute and Institute for Development and Peace.

Buzan, B. (1991). People, States and Fear: An Agenda For International Security Studies in the Post-Cold War Era, 2. wyd. Hertfordshire: Harvester Wheatsheaf.

Buzan, B., Wrver, O., de Wilde, J. (1998). Security: A New Framework for Analysis. Boulder: Lynne Rienner Publishers.

Keohane, R., Nye, J. (1977). Power and Interdependence. World Politics in Transition. Boston: Little, Brown and Company.

Kostecki, W. (1996). Europe After the Cold War. The Security Complex Theory. Warszawa: Instytut Studiów Politycznych PAN.

Musioł, M. (2015). Kompleks Bezpieczeństwa w regionie Azji Środkowej po 1991 roku. Warszawa: Dom Wydawniczy ELIPSA.

Stadtmüller, E. (2002). Pokój i bezpieczeństwo we współczesnym świecie. W: Z. Cesarz, E. Stadtmüller (red.), Problemy polityczne współczesnego świata. Wrocław: Wydawnictwo Uniwersytetu Wrocławskiego.

Taylor, B. (2012). National Security College Occasional Paper, No 3 April.

Waltz, K. (1979). Theory of International Politics. New York: Random House.

Williams, P.D. (2008). Security Studies. An Introduction. London, New York: Routledge. Vuori, J.A. (2011). How To Do Security With Words. A Grammar of Securitisation in the People's Republic of China. Turku: Turun Yliopisto, University of Turku. 